\title{
The Influences of the Performance of the Owner's Business And Personality-Based Small and Medium Enterprises: A Study on SME's in Sengkang Regency
}

\author{
NuraeniKadir \\ Department of Management,Faculty of Economy Hasanuddin University, Makassar Indonesia
}

\begin{abstract}
This research aimed to test and analyze empirically the influence of the owner's personality on their business strategy orientation and on the enterprise performance either directly or indirectly. The hypothesis test was conducted using the empirical data obtained through questionnaires from 365 owners of the small scale firms. The hypothesis test used the Structural Equation Modeling (SEM) and the result found was that the owners' personalities had significantly influenced the small firms' strategy orientations, the business orientation, and the owners' personality; that the business strategy had a dominat impact on the performance of their small enterprises. The theoretical implication gained in this study was that the finding had shown a correlation between the owners' personality, the business strategy orientation, and their impact on the performance of their small enterprises. The practical implication of this research suggests that in order to improve the performance of the small enterprises, training which can meet the personality of the owners of the small enterprises should be conducted.
\end{abstract}

Keywords: Personality, Business Strategy, Performance of the Small Sized Enterprises

\section{Introduction}

The primary characteristics of a small-sized firm were the low performance and the high level of failures caused by the external factors, such as the economic environment and the government policy which is often not oriented to develop the SME'S, the unstable input and prices of the raw materials, as well as the unfulfilled requirement of the product quality, of the work environment, the uncompetitive prices, the un-conducive government regulations, the lack of the access to the markets and to the capital resources.

While the internal factors impeding the performance and the success of the SME'S were among others, the incapable management and decision makers, the lack of experience, the weak financial control, the low quality of the human resources, the weak business management, the lack of access to the source of costs and markets, the lack of information and technology, and the tendency of the SME'S to wait for buyers.

The personality of the SME'S owners has a strong influence in the process of strategic planning, in determining the selection of the strategy types, in implementing the strategy and enterprise performance.According to Drago and Clements (1999) there have been very few researches which had related certain personality characteristics and its influence on the certain business orientation with the enterprise performance. Kotey and Meredith (1997) had found that empirically there was a correlation between the owners' personality, especially their personal values, and the type of business strategy which they chose to adopt in their enterprise operations and the performance of their enterprises. However, Kotey and Meredith (1997) did not tested the direct influence between the personal values of the owners/managers and the performance of their enterprises. Meanwhile, Porter in Bello (2003), Rashid (2003), Russel (2000), stated that the personality characteristics of the owners/managers became a very important factor because of its influence on other variables in an organization like the business strategy and the organization performance. Based on the above discussion, this research attempted to study the correlation between the personality of the SME'S owners, the developed business strategy orientation and the performance of the small sized firms in Sengkang Regency. The correlation between the personality, the business strategy, and the performance of the SME'S, which were based on the opinions of Porter in Bello (2003), Blackman (2003), Kotter and Hesket in Rashid (2003), and Wijewardena and Zoysa (2006) can be seen in the research model, Picture 1.

\section{Methodology}

The research population were the SME'sinSengkang Regency. The units of analysis were the owners who were also the managers of the SME's. Considering the variability of the types and the locations of the SME's, the sampling technique used was the disproportionate stratified random sampling technique (Kinnear and Taylor, 1995). 


\section{Picture 1. Research Model}

The characteristics of the owners' personality was measured based on the instrument developed by John and Srivastava (1999). While the business strategy orientation was measured using Miles and Snow's adaptation cycle of the SME'sto the environment.

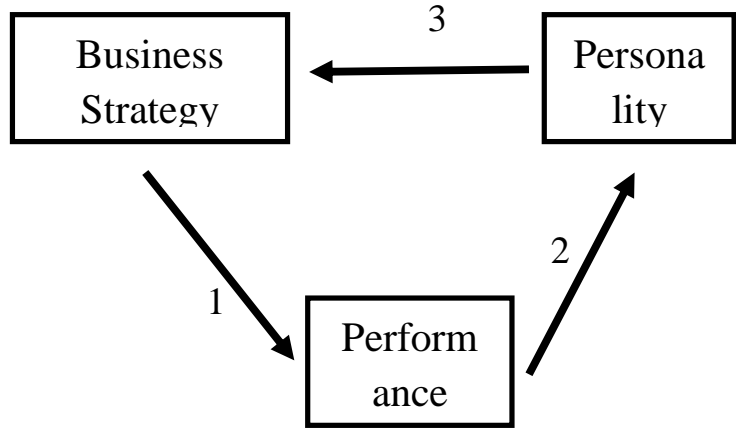

\section{Result And Discussion}

The Structural Equation Modeling analysis (SEM) with the AMOS version 5.0 procedure, in which the construct measurement covering the relative Chi-square value (X2df) in AMOS called CMIN/DF revealed the value of $1.27(<2)$; the value of the Comparative Fit Index was 0.942; and the value of Root Mean Square Error of Approximation was 0.027 indicated that the model hypothesis coud be accepted. The hypothesis test can be seen at Table 1.

Table 1. The Influence of the Dependent and Independent Variables in the Structural Model

\begin{tabular}{|c|c|c|c|c|c|c|c|}
\hline \multicolumn{2}{|c|}{ Influences of Variables } & \multirow{2}{*}{$\begin{array}{c}\text { Estimate } \\
-.411\end{array}$} & \multirow{2}{*}{$\begin{array}{l}\text { S.E } \\
.119 \\
\end{array}$} & \multirow{2}{*}{$\begin{array}{c}\text { Standardized } \\
-.255 \\
\end{array}$} & \multirow{2}{*}{$\begin{array}{l}\text { C.R } \\
3.461 \\
\end{array}$} & \multirow{2}{*}{$\begin{array}{c}\text { Probability } \\
\ldots\end{array}$} & \multirow{2}{*}{$\begin{array}{c}\text { Remark } \\
\text { Sig. }\end{array}$} \\
\hline $\begin{array}{l}\text { Business } \\
\text { Strategy }\end{array}$ & Personality & & & & & & \\
\hline Performance & $\begin{array}{l}\text { Business } \\
\text { Strategy }\end{array}$ & .264 & .052 & .355 & 5.099 & $\cdots$ & Sig. \\
\hline Performance & Personality & .020 & .085 & .017 & .236 & .813 & Non Sig. \\
\hline
\end{tabular}

3.1 The Influence of the Owners' Personality on the Business Strategy of the Small-Medium Firms (SME's)

The hypothesis test indicated that the business strategy had a positive and significant influence on the owner's personality, which means that the stronger the owner's personality, the stronger the business strategy the SME'sproduces. On the other hand, the weaker the weaker the culture the SME'stends to produce.The more extrovert the SME'sowner's personality, the stronger the business strategy the SME'stend to produce; on the other hand, the more directed the personality toward the openness to experience, the weaker the business strategy of the SME's.

The research revealed that the personality of the owners of the SME'stended to be strong and show the characteristics of listening to their conscientiousness and hence tended to produce stronger business strategy which had the characteristics of consistency and adaptability.

The hypothesis test indicated that the owners' personality had a strong influence on the business strategy of the Small-Medium Firms (SME's). That in managing their enterprises the SME'sowners relied on their carefulness and accuracy, perseverance and thoroughness, though they did not pay attention to the aspects of efficiency and worked without following the previously prepared plans. In other words, in managing their enterprises, the owners of the SME'stended to rely on their experience and intuition; consequently, when facing an environment change, they tended to be adaptive, i.e. reactive andwouldhaveto make a change only when they face a difficulty.

\subsection{The Influence of the Business Strategy on the performance of the Small-Medium Firms}

The hypothesis test revealed that the SME'swith the high performance would implement the business strategy which was directed to the prospectors. This finding indicated that the SME's which implemented the prospectors tended to produce higher performance. On the other hand, the SME's which implemented the business strategy toward the reactors tended to produce lower performance. This finding confirmed the researches by Davig (1986), Smith et al. (1988), and Luo (1999). Smith et al. !986) indicated that the firm which implemented the prospectors' strategy showed the characteristics as follows: unstable customer basis, changing product mixtures, competition-based innovation, creating changes in their basic customers, and aggressive growth tendency. 
The business strategy implemented by the SME's was more directed toward the defending strategy. Meanwhile, the performance of the SME's when viewed from the sale factor tended to show a rather high performance and produced small or low profit. As the hypothesis test showed, the SME's surveyed had a tendency to implement the business strategy or rather the competitive strategy which seemed to be directed more to high sales yet the profit remained low; hence the sales did not grow, and the SME's did not actually show any change in their competitive positions.

\subsection{The Influence of the Personality of the SME'sOwners on the SME'S Performance}

The hypothesis test revealed that the SME'S owners who had strong personality did not necessarily produce a high performance. This finding indicated that the personality of the SME'S owners did not necessarily bring out a difference in the SME'S performance.

William (1998) referred to the correlation between the measurement of the personality characteristics of conscientiousness and the difference of the indicators of the individual performance of the employees, such as the reliability of the employees, the personal discipline, and the personal efforts. The personality characteristics of conscientiousness became important because that personality characteristicswas related to the determining motivational performance. Hence, William (1998) could be used as a thought basis that the personality characteristics of the managers could influence indirectly the SME'S performance, but rather through the actions or the behaviours of the managers. The managers' actions or behaviours could be in the forms of the cultural development of the organizations and the formulation of the business strategy. The selection of the business strategy and the cultural development of the organizations were the forms of "actions" or the behaviours of the managers/owners.

\subsection{The Influence of the Owners' personality on the SME'S performance through the Business Strategy}

The hypothesis test indicated that the owners/managers' small enterprises who had strong personality seemed to possess the capacity to develop efficient business strategies and make the SME's perform highly. As Greenberg and Baron (2003) stated that various aspects of the personality often operated indirectly in influencing through specific factors of the actions and behaviors. The research result indicated that the personality of the SME'S owners influenced the business strategy orientations which was eventually influenced the SME'S performance.

Paige (2005) found that the influence of the owners in managing the organization was felt very strongly in the small enterprises, because the owners/managers'personality affected the selection of the business strategy and the performance of the small enterprises. Rue and Holland (1998) said that the personality characteristics of the managers were one of the many factors which could affect the managers in making the environmental decision, the strategic orientation, and the firm performance.

\subsection{Conclusion}

\section{Conclusion And Suggestion}

The SME'S owners' personality in fact influenced the orientation of the business strategy selection for their enterprises. Certain characteristics of the owners' personality could affect certain characteristics of the business strategies. The SME'S owners/managers who had strong personality were inclined to choose the competitive strategies toward the reactors; on the other hand, the SME'S owners/managers who had weaker personality would prefer to choose the business strategy orientation toward the prospectors. The owners/managers of the enterprises who had the conscientiousness characteristics of personality would prefer the business strategy which was directed toward the prospectors; on the other hand, those who had extrovert characteristics of personality would choose the business strategy orientation toward the reactors.

The difference of the personality characteristics of the SME'S owners/managers tended to show no difference in their performances. The reason was that in many aspects, the different personality characteristics did not show any direct influence on the enterprise performance. The strong-weak personality of the owners/managers influenced the development of the strong-weak business strategy and then indirectly influenced the high-low performance of the SME'S.The strong-weak personality of the owners/managers influenced the business strategy orientation or the competitive strategy which then indirectly influenced the high-low performance of the SME's.

\subsection{Suggestion}

The SME'S development must be directed by eliminating all the internal obstruction in order to change the behavior patterns, attitudes, and the skills of the small entrepreneurs in preparing the business plans. Changing the pattern of behaviors and attitudes can be done through training programs in which the trainees are those who understand and have practical experiences in managing the enterprises and the training method should be directed to the case method. 
The owners of the SME's should formulate the visions and the strategies of the enterprises. Then the visions and the strategies are often communicated using the simple and direct language/words and accompanied with real actions by the owners to the employees so that the employees have the same perspectives or views about the enterprises, share the common values about the enterprises, and are capable of growing their awareness that they are parts of the enterprises.

\section{Reference}

[1]. Drago, W.A., and Clements, C. 1999. Leadership Characteristics and Strategic Planning. Management Research News. Vol.22, No. 1, pp.11-18

[2]. Kotey, B., and Meredith, G.G. 1997. Relationships among Owner/ Manager Personal Values, Business Strategies, and Enterprise Performance, Journal of Small Business Management, pp. 37-61

[3]. Rashid, Z.A., Sambasivan, M., and Johari, J. 2003. The Influence of Corporate Culture and Organizational Commitment on Performance. Journal of Management Development Vol. 22 No. 2, pp.708-728

[4]. $\quad$ Russel, R.F. 2001. The Role of Values in Servant Leadership, Leadership \& Organization Development Journal 22/2, pp.76-83

[5]. Blackman, A.J. 2003. Entrepreneurs: Interrelation-ships between Their Characteristics, Values, Expectations, Management Practices and SME Performance, Doctor of Philosophy Thesis, Griffith University

[6]. Wijewardena, H., and De Zoysa, A. 2008. The Impact of Owner/manager's Mentality on the Financial Performance of SME's. Journal of Small Business and Enterprise Development, Vol. 15 No. 1, pp. 150-161.

[7]. Kinnear, T.C., Taylor, J.R. 1997. RisetPemasaran, EdisiKetiga. Jakarta: PenerbitErlangga.

[8]. John, O.P., Srivastava, S.1999. The Big Five Trait Taxonomy: History, measurement, and thereotical perspectives. New York: Guilford

[9]. Davig, W. 1986. Business Strategies in Smaller Manufacturing Firms.Journal of Small Business Management. Volume 24, No. 1, pp.38-46.

[10]. Luo, Xuemingand Bhattacharya, CB. 2006. Corporate Social Responsibility, Customer Satisfaction, and Market Value. Journal of Marketing Vol. 70 page 1-18.

[11]. Williams, R.S. 1998. Performance Management, Perspective on Employee Performance, International Thomson Business Press, London, UK

[12]. Greenberg, Jerald dan Robert Baron. 2003. Behavior in Organizations (Understanding and managing the human side of work ). Eight edition, Prentice Hall

[13]. Paige, R.C. 2005. An Examination of The Relationship Among Organizational Values, Strategies, Key Success, Skill, Culture and Performace of Micro-Businesses. Academy of Entrepreneurship Journal. Vol.11 Number 1, pp.35-57

[14]. Rue Leslie W. And Holland Phillis G. 1998.Strategic Management, McGraw-Hill Companies

[15]. Bamberger, I. 1983. Value Systems, Strategies and Performance of Small and Medium Sized Firms. International Small Business Journal 1 (4), pp.25-39

[16]. Hofstede, G. 1994. Cultures and Organizations, Software of the Mind, Intercultural Cooperation and its Importance for Survival, HarperCollins Publishers', Glasgow, UK

[17]. Hofstede, G., and McCrae, R.R. 2004. Personality and Culture Revisited: Linking Traits and Dimensions of Culture, Institute for Research on Intercultural CooperationTilburg, the Netherlands, 